\title{
Ethnologies
}

Recentering Anglo/American Folksong: Sea Crabs and Wicked

Youths. By Roger de V. Renwick. (Jackson: University of

Mississippi Press, 2001. Pp. xvi + 183, works cited, general

index, singer index, song index, ISBN 1-57806-393-0, cloth.)

\section{James Moreira}

Volume 25, numéro 1, 2003

Négocier la transcendance / Negotiating Transcendence

URI : https://id.erudit.org/iderudit/007137ar

DOI : https://doi.org/10.7202/007137ar

Aller au sommaire du numéro

Éditeur(s)

Association Canadienne d'Ethnologie et de Folklore

ISSN

1481-5974 (imprimé)

1708-0401 (numérique)

Découvrir la revue

Citer ce compte rendu

Moreira, J. (2003). Compte rendu de [Recentering Anglo/American Folksong: Sea Crabs and Wicked Youths. By Roger de V. Renwick. (Jackson: University of Mississippi Press, 2001. Pp. xvi + 183, works cited, general index, singer index, song index, ISBN 1-57806-393-0, cloth.)]. Ethnologies, 25(1), 274-279. https://doi.org/10.7202/007137ar d'utilisation que vous pouvez consulter en ligne. 
that the religious group who strives to bring a message to their listeners, must also be entertainers and businessmen, is an important theme of this book. Young effectively illustrates this tension not just for the Pilgrim Jubilees but also for the gospel singing industry as a whole.

This book was interesting and full of amazing detail and I wholly recommend it. It is based on meticulous research and the writing style is, for the most part, effective and accessible. I think, however, that Young removed his own presence from the work too thoroughly. This book is about more than a gospel group named the Pilgrim Jubilees. It is also about one researcher's, and one fan's, journey to pierce their depths and walk away inspired. Young argued that he wanted the group to stand alone and speak to the reader in their own words but I think that Young's own admiration for the group would have added another layer to the ethnography.

M. Lynn Gillingham

Memorial University of Newfounland

Saint John's

Recentering Anglo/American Folksong: Sea Crabs and Wicked Youths. By Roger de V. Renwick. (Jackson: University of Mississippi Press, 2001. Pp. xvi + 183, works cited, general index, singer index, song index, ISBN 1-57806-393-0, cloth.)

For over thirty years, one of the easiest ways to disparage a folkloristic study has been to call it "item-oriented." We have not abandoned text completely, but folklorists do pride themselves on having moved beyond the inherently philological approaches typified by the HistoricGeographic method, with its emphasis on indices and genre-based catalogues, and on type analyses rooted in the genealogy of tales or songs. For these approaches, "the text is [or was] the thing." All this, of course, is basic stuff for anyone with an Intro to Folklore course under their belt. So it comes as a surprise to find that a new major study of Anglo-American folksong - perhaps the first of the new millennium - reasserts the relevance, in fact necessity, of philological research in folklore. 
The work is a collection of five essays by Roger Renwick, written in an attempt, or so it says on the dustjacket, "to wrest folksong from contemporary theorists and return it to textual study." Two issues are implied, one of which is the push to reinvigorate textual analysis, which is an audacious objective all on its own. Renwick also takes on what he sees as a not-always-healthy dependency on "theory" in recent folklore scholarship. He expresses particular concern over a tendency toward "hypertheorizing," which occurs "when the act of theorizing rather than the illuminating of some body of data becomes the investigation's chief rationale" (xiii). The extent to which hypertheorizing has, in fact, become a problem in recent scholarship is open to debate, but Renwick is to be congratulated for at least initiating a discussion of the Emperor's new clothes.

To set the stage, he explores a particular instance where a researcher was, in Renwick's view, lead astray by putting a theory of song transmission and adaptation ahead of the textual evidence available. The target is a 1987 article by Roger Abrahams that explores "Creolization" in a small number of Afro-Caribbean variants of older British ballads, all of them Child types. Renwick especially challenges Abrahams's treatment of a variant from the Windward Islands, in cante fable form, of what appears to be "Little Musgrave and Lady Barnard" (Child 81; Roud 52; see Abrahams 120-26). There are clear narrative similarities between the Caribbean story-song and the well-known British ballad of adultery and revenge killing. Additionally, one of the central characters is named "Matty Glow," which strongly suggests a connection with the ballad character "Matty Groves." Creolization is observed in an increased use of prose narrative (refrains, really, are all that is left of the song), and in the presence of a bird acting as informer, which, in Abrahams's assessment, shows the influence of African Anansi tales.

Renwick argues, however, that neither feature indicates necessarily a departure from the ballad's British roots. Cante fable variants, he notes, are not uncommon in Anglo-American ballad tradition, and the character of the bird, rather than suggesting the influence of African narrative tradition, probably indicates that the source ballad is not Child 81 , but the much less common but related ballad, "The Bonny Birdy" (Child 82), which features a virtually identical character. Renwick then offers his own explanation for the influences shaping St. Vincentian tradition through an evaluation of the broader Caribbean tradition. He shows that a significant number of Carribean ballad traits - 
including some that Abrahams views as African syncretisms - are found primarily among older British versions or, more broadly, in older European ballad traditions. Caribbean balladry, in his view, can be explained as easily by the retention of these older features as by syncretic adaptation.

Ultimately, all arguments and counter-arguments hinge on the relative weight given to details. For example, Abrahams, who was aware of Renwick's criticisms prior to the publication of the initial paper, counters that the name "Matty Glow" is convincing evidence of a connection to Child 81. Renwick in turn observes that the Caribbean variant curiously gives the name to the female rather than the male character (the latter, in this text, is named Garoleen). Therefore, the name does not indicate direct affinity. But if Renwick is correct that Caribbean tradition reflects older European ballad traits, and assuming at the same time that "Matty Glow" has some connection to the name common in Anglo-American tradition - the similarity is too close to reject it entirely - , how then does he account for the fact that the name "Matty Groves" occurs only in more recent and overwhelmingly American versions of Child 81 (cf. the nearly 200 versions listed in Roud)? One can only accept that the cross-fertilizations of ballad tradition are far too complex to be accounted for by individual theories, and to be fair, in broad scope, that is one of Renwick's principal arguments. In making his case, he amply shows that theory that proceeds without comprehensive appreciation of the textual record discards, at its peril, one of folkloristics' great strengths: our comparative knowledge of the historical depth and geographic breadth of tradition.

The remaining chapters deal more concretely with textual analysis. Chapters two and four are exercises in type delineation; chapter three discusses a pervasive compositional trait in Ango-American folksong; the last chapter, moving well beyond the confines of Anglo-American folk tradition, examines international variants of a single type, taking into account the song's general psychological functions as well as its more contextually grounded significances. I shall treat the chapters in the above order.

The type analyses are the most challenging parts of the book, not so much for their provocativeness as for the simple reason that they seem completely unexpected in contemporary folkloristics. Both are detailed explorations of textual relationships, very reminiscent of the 
masterful connections that Wilgus was able to trace in "The Text is the Thing." While reading them, however, I kept wondering how many folklorists at the present time would actually care about the textual history of "Newry Town" and its American offshoots or whether "Oh Willie" truly does represent a distinct type from "The Butcher Boy." It's hard to imagine that these articles will initiate a new spate of likeminded research, the way Renwick's earlier collection of essays inspired a generation of folklorists - myself included — to undertake interpretative analyses of traditional song. But they do reflect an engagement with text that the discipline in general has lost. Had folklorists truly abandoned text, that would not be an issue, but we haven't. Our work is still very much rooted in the analysis of text, of motif, of narrative theme, of type, and of genre. These are terms and concepts that we continue to deal with on a daily basis, and it is helpful to be reminded of what "close reading" actually means.

The third essay is literally and figuratively the centerpiece of the collection and marks its strongest contribution to the discipline. Since the days of the Romantic revival, Anglo-American folksong has been carved into two major sub-genres: narrative and lyric. Occasionally, "descriptive" is added as a third category; however, if research on lyric song has been at best sparse, studies of descriptive song are virtually nonexistent. Renwick offers an extended discussion of another formal class which he terms "catalog" songs. Its defining characteristics are that it "articulates its images additively: it inventories or lists them so that they constitute an assemblage of parts that, while unified by a common empirical quality such as contiguity, comprise a whole that's not much more than the sum of those parts" (61). Such common forms as cumulative songs - "The Green Grass Grew All Around," "The Bog down in the Valley-O" — and certain kinds of dialog songs "The Quaker's Courtship," "There's a Hole in the Bucket," and even "Our Goodman" (Child 274: "Seven Drunken Nights") — are among the more obvious examples, but broadly viewed, the amount of material that could be incorporated under the heading is nothing short of vast. It includes much of what is often regarded as "functional song" shanties, play-party and dance songs, and many lullabies — which until now has often been used as a misfit addendum to the formal categories. But the identification of the catalog song does more than just round out a classification system grounded in formal criteria. It also identifies a compositional technique, the influence of which is detectable in many 
kinds of songs. In ballads, incremental repetition and such devices as the "climax of relations" exemplify the catalog principle on a micro scale. The catalog song also has obvious implications for theories of formulaic composition in Anglo-American tradition. This is a groundbreaking essay and should be essential reading for any student of folksong or folk literature.

The final essay combines detailed textual analysis with interpretation. The subject is a well-known bawdy ballad, "The Crabfish Song," which tells the story of a woman who, by various causes, has her genitals grabbed by a crab or lobster. A man coming to her rescue is then grabbed by the nose, leaving both characters in a compromising situation, in which they are discovered by friends and neighbours. Renwick's approach to the song is multilayered, drawing on texts from different class and gender backgrounds, from literary reworkings of the theme, and from historical and international traditions, including nonWestern sources. Through careful attention to commonalities and textual differences, he is able to suggest universal psychological functions for the song and identify meanings that are more contextually contingent. He even uses the song as an entrée to the politics of fieldwork through a discussion of a version collected by Cecil Sharp from one of his female informants. The comprehensiveness of the study is its clear strength. However it also points to innate weaknesses in comparative method. The Freudian implications of the song, for example, are seen to exist on a number of levels, one which is a fear of castration (the crab fixed to the woman's "front" is linked to the vagina dentata motif, and the man's nose understood euphemistically as penis finishes the connection — or disconnection as the case may be!). Support for this anxiety's implicit relevance to the song as a cross-cultural entity, however, is linked to a secondary narrative element in variant from India, in which the character who frees the joined couple subsequently has his own genitals clawed by a cat. This is seen as explicit evidence for the phobia, and perhaps it is for that particular context. Yet the reader has to question whether the evidence speaks broadly to meaning at the level of type or whether it should be limited to a consideration of the variant alone. Philological approaches are, as Renwick argues, rooted in empirical evidence: texts. But the diffusionist links that folklorists have established between texts exist primarily in theory, and, as substantial as our databases are, we rarely have access to a detailed record that would help us put more solid flesh on the bones of tradition. I find it difficult 
to accept readings of core meaning that are based on rare and remote variants.

Relatively minor criticisms aside, Recentering Anglo-American Folksong is an important collection of essays. In the current interpretive environment, scholarship sometimes appears to possess the license to say anything. It is therefore gratifying to read studies that put data first and that have as their principal goal the illumination and understanding of the lore itself. That, after all, is what I signed up for.

\section{References}

Abrahams, Roger D. 1987. "Child Ballads in the West Indies." Journal of Folklore Research 24: 107-34.

Roud, Steve. 1994-present. Folksong Index. Electronic Database. Maresfield, Sussex: Steve Roud.

Wilgus, D.K. 1973. "The Text is the Thing." Journal of American Folklore 86: $241-52$.

James Moreira University of Maine

Orono

The Heavens are Changing: Nineteenth-Century Protestant Missions and Tsimshian Christianity. By Susan Neylan. (Native \& Northern Series 31. Montréal: McGill-Queens University Press, 2003, \$76,00. Pp. xvii + 401, ill., photographs, diagrams, maps, ISBN 0-7735-2327-8, cloth.)

The Tsimshian have lived at the West coast and Skeena and Nass drainages of northern British Columbia long enough to develop a distinctive expression of West Coast culture and to enrich that expression from traditions transmitted by other natives. The traditional heart of the Tsimshian way was the development of the self. The ancestral kin of aristocrats encountered supernatural figures, as myths described and rituals portrayed: in this way, Chiefs received status and power. Individuals of any class, visited by vision and trials of the spirit, might actively achieve a Shaman's vision, status and power to heal. A complex of danced rites, some acquired as the ideas that embodied them travelled from the South, provided means for those who could afford to mount them to pass through public, programmed transformations with supernatural aid, personified by supporting dancers. This novel 